\title{
SOCIAL PEDAGOGY/SOCIAL WORK IN GERMANY
}

\author{
THEORIES AND DISCOURSES IN SOCIAL PEDAGOGY AND SOCIAL WORK: FROM \\ DISCIPLINARISATION OF THE POOR TO AN EMANCIPATORY DEMOCRATIC PERSPECTIVE
}

\author{
PEDAGOGÍA SOCIAL/TRABAJO SOCIAL EN ALEMANIA \\ TEORÍAS Y DISCURSOS DE LA PEDAGOGÍA SOCIAL Y EL TRABAJO SOCIAL: DE LA DISCIPLI- \\ NARIZACIÓN DE LOS POBRES A UNA PERSPECTIVA DEMOCRÁTICA DE EMANCIPACIÓN
}

\section{A PEDAGOGIA SOCIAL/TRABALHO SOCIAL NA ALEMANHA DISCURSOS TEORIAS E EDUCAÇÃO SOCIAL E SERVIÇO SOCIAL: A PARTIR DO DISCIPLI- NAMENTO DOS POBRES A UMA PERSPECTIVA DEMOCRÁTICA DE EMANCIPAÇÃO}

\author{
Heinz Suenker
}

WUPPERTAL UNIVERSITY

\section{Rita Braches-Chyrek}

UNIVERSITY OF BAMBERG

\begin{abstract}
The paper reconstructs developments of ideas and practises of social pedagogy/social work in the context of the social history of the German States from the inception of bourgeois-capitalist society up to contemporary times. Against the background of persisting structural social inequality this historical approach builds a bridge between the poor laws of the 16th century and the new labour/green laws 'Hartz IV' at the end of the 2oth century. What becomes evident is a common leitmotif: the pedagogisation of the work habits of the ordinary people. Modern social pedagogy approaches fight this attempt as the reconstruction shows in the interest of the defense of real education ("Bildung") and therefore the autonomy of life praxis of all. Social pedagogy can therefore be called - since the beginning of the 2oth century - a discipline and profession which is mediated to ideas of real democracy and therefore deals with the question how to change capitalism.
\end{abstract}

KEYWORDS: Social inequality, education, social change, professionalisation, democracy.

RESUMEN: El artículo reconstruye el desarrollo de ideas y prácticas de la pedagogía social en el contexto de la historia social de los estados alemanes desde el inicio de la sociedad burguesa capitalista hasta la actualidad. Frente al persistente contexto de desigualdad social y estructural este enfoque histórico construye un puente entre las insuficientes leyes del siglo XVI y las nuevas leyes laborales/verde 'Hartz IV' de finales del siglo XX. Lo que pone de manifiesto un leitmotiv común: la incursión de la pedagogía en los hábitos de trabajo de la gente común. Los enfoques de la pedagogía social luchan contra este intento como 
se muestra en la reconstrucción en aras de la defensa de la economía real ("Bilding") y por extensión de la autonomía de su praxis. Por tanto, desde principios del siglo XX, la pedagogía social se puede considerar una disciplina y una profesión llena de ideas de democracia real y que trata de dar respuesta a la pregunta sobre cómo cambiar el capitalismo.

PALABRAS CLAVE: Desigualdad social, educación, cambio social, profesionalización, democracia.

RESUMO: O artigo reconstrói a evolução de ideias e práticas da pedagogia social/trabalho social no contexto da história social dos estados alemães desde o início da sociedade burguesa -capitalista até os tempos contemporâneos. No contexto de persistente desigualdade social estrutural esta abordagem histórica constrói uma ponte entre as leis dos pobres do século XVI e do novo trabalho / leis Hartz IV 'verdes "no final do século 20, o que se torna evidente é uma questão comum: a pedagogização dos hábitos de trabaIho das pessoas comuns. As abordagens da pedagogia social moderna lutam contra esta lógica, buscando a reconstrução da defesa da educação real "Bildung" e, portanto, para a autonomia de todos, tendo por base a práxis. A Pedagogia social pode, portanto, ser chamada - desde o início do século 20 - uma disciplina e profissão que é mediada para ideias de democracia real e, portanto, preocupada com a questão de como mudar o capitalismo.

PALAVRAS-CHAVE: Desigualdade social, educação, mudança social, profissionalização, democracia.

\section{Writing History and Poor Relief}

The history of social pedagogy and social work ${ }^{1}$ in Germany, for the last 30 years or so designated as 'Soziale Arbeit' ('societal work') to encompass both, is embedded in the social history of the German States from since the times of the old empire (the Holy Roman Empire of the German Nation) up until the Federal Republic of Germany ${ }^{2}$. Its development can be read as a process from the open disciplinarisation of the poor (since early transitions from feudalism to capitalism) to an emancipatory democratic theorising - while still often oppressive in practise (in late capitalism).

In this context the key principle highlighted by Hans-Ulrich Wehler of a social history based approach in social analysis is particularly applicable to both social pedagogy and social work: "The development of German society in the previous two centuries is fundamentally characterised by the persistence of structural social inequality too. This is perhaps the key question for any historical social research, any stratification analysis, any social history - not least because it necessarily draws attention to the life chances of many individuals", Wehler, 1987:16) ${ }^{3}$. In terms of its analytical positioning

\section{Historia escrita y Asistencia de los Pobres}

La historia de la pedagogía social y el trabajo social' en Alemania, conocida durante los últimos 30 años como "Soziale Arbeit" (Trabajo Social) para abarcar a ambos, encaja en la historia de los estados germánicos desde la época del imperio antiguo (El Santo Imperio Romano de la Nación Alemana) hasta la República Federal de Alemania ${ }^{2}$. Su desarrollo se puede entender como un proceso que va desde la clara disciplinarización de los pobres (desde las primeras transiciones de feudalismo a capitalismo) hasta la teoría de la democracia participativa - mientras que en la práctica sigue siendo opresiva (en el capitalismo tardío).

En este contexto, el principio clave destacado por Hans-Ulrich Wehler (un enfoque de historia social basado en el análisis social) es especialmente aplicable a la pedagogía social y al trabajo social: "El desarrollo de la sociedad alemana en los dos siglos anteriores también se caracterizaba principalmente por la persistencia de la desigualdad social estructural. Puede que esta sea la pregunta clave para cualquier investigación social histórica, cualquier análisis de estratificación, cualquier historia social - y no solo porque siempre centre la atención en las posibilidades de vida de muchas personas", Wehler, 1987:16. ${ }^{3}$ En 
Wehler's assessment is that the system of social inequality is assigned such significance in every society that it appears justified to treat this system as one of the central axes of social analysis. "We should be clear, however, and remain conscious of that fact that social inequality -... is fundamentally the result of the interaction of inequality in the distribution of power, economic circumstances and a culturally determined view of the world. It is therefore a result of the overlap of the three systemically determined dimensions (economics, power and culture, the authors)" (Wehler, 1987:11).

The question about the processes which define the formation of social classes is closely intertwined with the analysis of social inequality and needs to be deciphered historically and systemically (see Kocka 1990a + b). The analysis of class formation is at the heart of the analysis by Lenhardt and Offe (1977) who present their social policy based "proletarianisation theory" which deals with "the state tackling the problem of a lasting transformation of non-waged into waged labourers" (1977:101) and is therefore directly relevant to social work.

A reconstructive approach shows that the development of the discipline and profession of social work in the German states/regions and throughout Europe as a whole has its beginning in the history of caring for the poor and its institutionalisation. In the towns and cities of the late middle ages/early modern times (in Germany for example at the beginning of the $16^{\text {th }}$ century) two such rudimentary institutions were already emerging: the hospital and the regulation of begging of the poor and of alms giving, which were developed and implemented as strategic responses to social need. However, up until well into the $16^{\text {th }}$ century, the distribution of support to the poor in many rural areas did not follow either a social policy rationale nor was it subject to the primacy of rationality: giving was shaped by the norms of Christian charity. The fundamental motivation for rich benefactors was the hope of buying "salvation" by giving to the poor (see Sachße \& Tennstedt, 1980: 23, 29f.; Mollat 1987). The establishment and maintenance of civic institutions which implemented more or less consistent poor laws - based on bureaucratisation and educationalism starting with the poor laws of Nuremberg in 1525 - was only advanced by existing power structures and interventions in términos de posicionamiento analítico, la evaluación de Wehler revela que el sistema de desigualdad social tiene tanta importancia en la sociedad que parece que se justifique el tratar al sistema como uno de los ejes centrales del análisis social. "Por lo tanto, hemos de ser claros y seguir siendo conscientes del hecho de que las desigualdades sociales -(...) son básicamente el resultado de la interacción de la desigualdad en la distribución de poder, las circunstancias económicas y la visión del mundo determinada por la cultura. Por lo tanto es el resultado de la superposición de las tres dimensiones sistémicas determinadas (economía, poder y cultura)" (Wehler, 1987:11).

La pregunta sobre los procesos que definen la formación de las clases sociales está íntimamente relacionada con el análisis de la desigualdad social y debe ser descifrado histórica y sistémicamente (véase Kocka 1990a + b). El análisis de la formación de clases es la base del análisis de Lenhardt y Offe (1977) quienes presentan su política social basada en "la teoría de la proletarización" que aborda "el estado enfrentando el problema de una paulatima transformación, pasando de ser no asalariados a obreros asalariados" (1977:101) y por lo tanto es directamente relevante para el trabajo social.

Un enfoque reconstructivo muestra que el desarrollo de la disciplina y la profesión de trabajo social en los estados/regiones alemanas y en toda Europa comienza en la historia del cuidado de los pobres y su institucionalización. En los pueblos y ciudades de finales de la edad media o principios de la era moderna (en Alemania por ejemplo a principios del siglo XVI) surgieron dos instituciones rudimentarias: el hospital y la regulación de la mendicidad y la limosna para los pobres, que se desarrolló e implementó como respuesta estratégica a la necesidad social. Sin embargo, hasta bien entrado el siglo XVI, la distribución de ayuda a los pobres en muchas áreas rurales no siguió un racionamiento de política social ni se aplicó de manera racional: estaba sujeto a las normas de la caridad cristiana. La motivación fundamental de los benefactores ricos era la esperanza de comprar "la salvación" dándo a los pobres (ver Sachße \& Tennstedt, 1980: 23, 29f.; Mollat 1987). El establecimiento y conservación de las instituciones cívicas que implementaron unas leyes para pobres más o menos consistentes - basadas en burocratización y educacionalismo partiendo de las leyes de 
the context of the establishment and enforcement of capitalism (Sachße/Tennstedt 1980: 34). The increasing social division of labour in small-scale manufacturing and the advancing of trade and increasing circulation of a variety of products favoured diverse rural and urban ways of life, which relied on the realisation of labour as a commodity (see Marx, 1857/1993: 250-401).

The ruling classes controlled economic processes, but at the same time evaded the social control of the economic and social plight caused by them since the inception of the capitalist system. Legal processes and the public institutions' modes of operation did not always conform to the social and cultural perceptions and interpretations of poverty, i.e. the "moral economy" of the majority still functioned on the part of those now to be disciplined or the persecuted. This produced resistance of the people against the new morals (see Sachße \&Tennstedt, 1989: 38). The most important element of the accepted distinction between deserving/undeserving was the introduction of bureaucratic institutions which objectified, i.e. pushed through publicly endorsed classifications and applied these to groups or individuals; the decisive criterion was -for capitalist bourgeois society still is- the readiness to demonstrate a willingness to work. Authoritative boundaries between groups, through creating collective representations or a symbolic order, assigned the poor a legitimate or an illegitimate place in their social environment. The only means by which groups of the poor could escape the repressive measures associated with social welfare was to work towards changes in ideological and religious world views, and the conscious rejection or withdrawal from the controlling and all pervading grasp of the ruling class (Raphael, 2004, p. 15 f.; Geremek, 1988, p. 300).

With the transition from feudalism to capitalism a new mode of societalisation was established, which formally marked the beginning of a system of personal independence, as Marx calls it, based on objective dependence (Marx, 1993: 158), a change from the typically pre-capitalist personal dependence. This established the possibility of being an owner of one's labour-power, juxtaposed with or opposed to the "capitalist". This gave rise to historically tangible general and specific contradictions between individual and society. "In short: It is the task of social pobres de Nuremberg en 1525 - sólo fue superado por estructuras de poder existentes e intervenciones en el contexto de la creación y aplicación del capitalismo (Sachße/Tennstedt 1980: 34). El aumento de la división social del trabajo a pequeña escala en la fabricación y el avance del comercio y el incremento de la circulación de una variedad de productos favoreció diversas formas de vida rurales y urbanas, basadas en la realización del trabajo como una mercancía (véase Marx, 1857/1993: 250-401).

Las clases dominantes controlaban los procesos económicos, pero al mismo tiempo evadieron el control social de la situación económica y social causada por ellos desde la implantación del sistema capitalista. Los procesos legales y las formas de operación de las instituciones públicas no siempre se ajustan a las percepciones sociales y culturales y a las interpretaciones de la pobreza, es decir, la "economía moral" de la mayoría todavía la llevaron a cabo aquellos que ahora son castigados o perseguidos. Esto produjo una resistencia del pueblo contra la nueva moral (véase Sachße \& Tennstedt, 1989:38). El elemento más importante de la distinción entre los merecedores/indignos fue la introducción de instituciones burocráticas que objetivaron, por ejemplo, mediante clasificaciones públicamente apoyadas y aplicándolas a grupos o individuos; el criterio decisivo era -y sigue siendo para la sociedad burguesa capitalista- estar listo para demostrar voluntad por trabajar. Los límites de autoridad entre grupos, mediante la creación de representaciones colectivas $u$ ordenes simbólicas, concedieron a los pobres un lugar legítimo o ilegítimo en su entorno social. El único medio por el cual los grupos de pobres podían escapar de las medidas represivas asociadas con el bienestar social fue trabajar para crear un cambio en la visión ideológica y religiosa, así como rechazar de forma consciente o alejarse de las garras de la clase dominante que lo controla y domina todo (Raphael, 2004, p. 15 f.; Geremek, 1988, p. 300).

Con la transición del feudalismo al capitalismo se estableció una nueva visión de sociedad, que marcó formalmente el inicio de un sistema de autonomía personal, como lo llama Marx, basado en la dependencia objetiva (Marx, 1993:158), en contraposición a la típica dependencia personal del pre-capitalismo. Esto estableció la posibilidad de ser dueño del propio poder de trabajo en yuxtaposición con o

[ 22 ] HEINZ SUENKER, RITA BRACHES-CHYREK

SIPS - PEDAGOGIA SOCIAL. REVISTA INTERUNIVERSITARIA [1139-1723 (2016) 27, 19-44] TERCERA ÉPOCA 
pedagogy to address the risks emanating from capitalist economies" (Winkler, 1995a: 173; cf. Sünker, 1995a).

Social work can often be located in the conflict between society and the individual and continues to function historically and to the present day largely as a means to enforce social normality. It is therefore often socio-politically exploited and has continued to prove an effective means of reproducing society in its present form. Deviation is defined as an individual problem within an educational framework of society and politics (Sünker, 2003).

Despite the current Foucault inspired tendency to view this as a new phenomenon, early shoots of infringement on individuality can historically be traced back to early bourgeois society. In his "Philosophy of Right" (at the beginning of the 19th century) Hegel's description of the contradictions inherent in civil society highlights the systemic nature of the problem early on. It thematically raises the question of patterns of societalisation in its effect on the existence and constitution of members of bourgeois society. It deals with form and substance of the relationship of the members of bourgeois capitalist societies with each other, which finds a distinct expression in their independence as individuals. In the context of these preconditions the also resulting external interdependence of independent individuals (Hegel, 1821/1967: §§ 182 and 183) causes structural and practical contradictions: "In these contrasts and their complexity, civil society affords a spectacle of extravagance and want as well as of the physical and ethical degeneration common to them both." (Hegel, 1967: § 185).

This view of the reality of civil society, developed by Hegel and heavily influenced by his study of the Scottish moral philosophers, leads him to postulate the social inevitability of a corresponding development defined by its own character: This includes the tendency "to multiply and subdivide needs, means, and enjoyments indefinitely" (1967: \$195) and the fact that "the standard of living of a large mass of people falls below a certain subsistence level" - leading to the decline into or the reality of absolute poverty as a mass phenomenon. "At the same time this brings with it, at the other end of the social scale, conditions which greatly facilitate the concentration of disproportionate wealth in a few hands" (1967: §244). contra el "capitalista". Esto dio lugar a las contradicciones generales y específicas históricamente tangibles entre individuo y sociedad. "En definitiva: $\mathrm{La}$ pedagogía social debe abordar los riesgos que emanan de las economías capitalistas"(Winkler, 1995a: 173; CF. Sünker, 1995a).

En muchas ocasiones encontramos el trabajo social en el conflicto entre la sociedad y el individuo y desde la antigüedad hasta nuestros días, en gran parte como un medio para imponer la normalidad social. Por lo tanto muchas veces se explota desde el punto de vista social y político y ha dejado de ser un medio eficaz de reproducir de la sociedad en su forma actual. La desviación se define como un problema individual dentro de un marco educativo de la sociedad y la política (Sünker, 2003).

A pesar de la corriente actual inspirada en Foucault de verlo como un fenómeno nuevo, hemos de remontarnos a la sociedad burguesa para localizar los primeros momentos en los que se ataca el individualismo. En su "Filosofía del Derecho" (a comienzos del siglo XIX) la descripción de Hegel de las contradicciones inherentes a la sociedad civil pone de relieve la naturaleza sistémica del problema desde sus comienzos. Se plantea la cuestión de los patrones de creación de la sociedad en base al efecto que produce sobre la existencia y la constitución de los miembros de la sociedad burguesa. Trata en su forma y esencia la relación establecida entre los miembros de la sociedad capitalista burguesa, en la que existe una expresión distinta en su independencia como individuos. De acuerdo con estas condiciones previas la interdependencia externa que presentan los individuos independientes (Hegel, 1821-1967: §§ 182 y 183) provoca contradicciones tanto prácticas cómo estructurales: «En estos contrastes y su complejidad, la sociedad civil ofrece un espectáculo de extravagancia, así como la degeneración física y ética común a los dos». (Hegel, 1967: § 185).

Esta visión de la realidad de la sociedad civil, desarrollada por Hegel muy influenciado por su estudio sobre los filósofos morales escoceses, lo lleva a postular la inevitabilidad social del desarrollo correspondiente definido por su propio carácter: Esto incluye la tendencia "a multiplicar y subdividir indefinidamente las necesidades, medios y placeres" (1967: §195) así como el hecho de que "el nivel de vida de una gran cantidad de personas se sitúa por debajo 
Hegel points out that poverty contravenes a human's self-respect which makes him insist on maintaining himself by his own work and effort and without the help of others. This establishes the regulatory concept of bourgeois capitalist forms of society which became a key focus of social work.

In his study of the origins of social pedagogy in Germany, Mollenhauer highlights social pedagogy's view of bourgeois society as characterised by "cultural decay" as a determining factor in its own genesis and frame of reference. As a result, its professional objective becomes the drive for "comprehensive social regeneration" which aims at the "whole of society as the target of education" (Mollenhauer, 1959: 121-122).

Social pedagogy/social work has therefore missed its objective from the start, as it uses accepted pre-modern concepts of community and the "regeneration of community" as its reference point, whereas -as Hegel's analysis shows- civil society always produces its own contradictions as a society. A direct result of this mistake is the individualised approach of social work interventions with individuals, groups and classes with the aim to "normalise" - be it legitimised by philanthropy, "moral panic" or the rhetoric of dangerous classes.

\section{Poor relief and capitalism}

Social policy in the $19^{\text {th }}$ century 4 was characterised by measures to control and discipline the poor and by provision which was linked to individual need and intervention strategies and directed by internally and externally enforced mechanisms of institutionalised normative control - and more than marginally through workhouses and correctional institutions. There were municipal and state specific regulations, which could vary significantly in their respective manifestations. Universally accepted guidance, regulations or legislation was, however, not issued. Church de un cierto nivel de subsistencia" - lo que conduce al declive o la realidad de la pobreza absoluta como fenómeno de masas. "Al mismo tiempo esto significa que en el otro extremo de la escala social se propicien condiciones que faciliten enormemente una concentración desproporcionada de riqueza en unas pocas manos" (1967: §244). Hegel señala que la pobreza contraviene el amor propio del ser humano que le hace persistir por mantenerse a sí mismo con su propio trabajo y esfuerzo sin la ayuda de los demás. Esto establece el concepto regulador del capitalismo burgués de la sociedad que se convirtió en un punto clave para el trabajo social.

En su estudio sobre los orígenes de la pedagogía social en Alemania, Mollenhauer destaca la visión de la pedagogía social sobre la sociedad burguesa caracterizada por "la decadencia cultural" como factor determinante en su propia génesis y marco de referencia. En consecuencia, su objetivo profesional persigue la "regeneración social integral" que pretende llegar "al conjunto de la sociedad como objetivo de la educación" (Mollenhauer, 1959:121-122).

Por tanto, la pedagogía social/trabajo social no ha alcanzado su primer objetivo, ya que se vale de conceptos modernos de comunidad y "regeneración de la comunidad" como punto de referencia, mientras que - como muestra el análisis de Hegel - la sociedad civil siempre genera sus propias contradicciones como sociedad. Consecuencia directa de este error es el enfoque individualizado en las intervenciones de trabajo social con individuos, grupos y clases con el objetivo de "normalizar", ya sea legitimado por la filantropía, "pánico moral" o la retórica de las clases peligrosas.

\section{Capitalismo y asistencia de los necesitados/ pobres}

La política social en el siglo XIX 4 se caracterizó por la creación de medidas para controlar y disciplinar a los pobres/necesitados con ayudas vinculadas a la necesidad individual y las estrategias de intervención, dirigidas con mecanismos de control normativo institucionalizado, tanto interna como externamente, más allá de hospicios y correccionales. Existían regulaciones específicas municipales y estatales, que podrían variar significativamente en sus diferentes manifestaciones. Sin embargo, no se establecieron

[ 24 ] HEINZ SUENKER, RITA BRACHES-CHYREK

SIPS - PEDAGOGIA SOCIAL. REVISTA INTERUNIVERSITARIA [1139-1723 (2016) 27, 19-44] TERCERA ÉPOCA 
based charities and private institutions were generally responsible for welfare provision and poor relief. The main political aim was to provide protection and security for the ruling classes from the masses of the poor, the welfare of the workers was of minor importance. The emergence of social reforms capable of developing concrete social policy demands and achieving political change led to the passing of new legislation in 1842, which was introduced throughout the whole of the German empire (Salomon, 1921/2004, p. 106ff).

Assuming these concepts as a measure of the desirable, the development of the usually denominational charitable institutions providing care for children, the youth, families and the sick as well as the semi-public municipal initiatives of the Elberfelder and later the Strasbourg model, charged with providing the main welfare services for the poor, constitued a further necessary step. These institutions retained a traditionally Christian paternalistic model. i.e. they combined a concept of charity with the idea of a "just" paternalism that included a mandate to impart social behaviours viewed as desirable and successful according to bourgeois norms. Influenced by Malthusian ideas, poor relief was kept to a minimum, any educational intervention was considered superfluous and even the support of children was only based on the principles of poor relief. This constituted a relapse back to before the achievements of the Hamburg alms houses of the $18^{\text {th }}$ century (Salomon, 1921/2004, p. 113). The initially very modest protective regulations in the context of working time rules and protective measures around health and safety at work led at the same time - especially in the big cities - to new arrangements for poor relief in the municipal districts with volunteer male carers and principals, and to the development of social security arrangements through social insurance systems (Sachße \& Tennstedt, 1986, p. 31; Salomon, 1901/1997, p. 90f).

These approaches combined several aims. The primary aim was the "civilising" of the lower class in general, but also the regulation of the worrying and destabilising potential of the underprivileged masses and the reform of insufficient private welfare by the deployment of more effective help from the state with the aim of achieving social control by imposing social discipline. These change processes were fa- ni directrices ni normativas ni legislaciones universalmente aceptadas. Las obras de caridad de la iglesia y las instituciones privadas solían ser las encargadas de suministrar bienestar y asistencia a los pobres/necesitados. El principal objetivo político era brindar protección y seguridad a las clases dominantes frente a las masas de pobres; el bienestar de los trabajadores tenía una importancia residual. La aparición de las reformas sociales capaces de desarrollar políticas sociales concretas y el cambio político dio lugar a la aprobación de nueva legislación en 1842, que fue introducida por todo el Imperio alemán (Salomon, 1921/2004, p. 106ff).

Si asumimos estos conceptos como lo que sería deseable, el desarrollo de las denominadas tradicionales instituciones caritativas para cuidar de los niños, los jóvenes, las familias y enfermos así como las iniciativas municipales semipúblicas de Elberfelder y el posterior modelo de Estrasburgo, (encargado de proporcionar los principales servicios de bienestar a los pobres), constituyen un paso adicional necesario. Estas instituciones conservan un modelo paternalista tradicional cristiano, es decir, combinaron el concepto de caridad con la idea de un paternalismo "justo" que incluía la obligación de difundir comportamientos sociales considerados deseables y satisfactorios según las normas burguesas. Influido por las ideas maltusianas, la asistencia a los pobres se mantuvo en el mínimo, cualquier intervención educativa se consideraba superflua e incluso el apoyo a niños se basaba solo en los principios de asistencia al pobre/necesitado. Esto supuso una recaída a niveles inferiores a los alcanzados por las casas de almas de Hamburgo del siglo XVIII (Salomon, 1921/2004, p.113). Las regulaciones de protección inicialmente muy modestas en el contexto de las reglas de tiempo de trabajo y las medidas de protección de salud y seguridad en el trabajo desembocaron al mismo tiempo -especialmente en las grandes ciudades- en nuevos acuerdos en materia de asistencia al necesitado en los distritos municipales con cuidadores masculinos y directores voluntarios y el desarrollo de los acuerdos de seguridad social a través de sistemas de seguros sociales (Sachße \& Tennstedt, 1986, p. 31; Salomon, 1901/1997, p. 9of).

Estos enfoques combinaban varios objetivos. El objetivo primario fue "civilizador" para la clase baja 
cilitated by a general strengthening of pedagogical beliefs and attitudes and a growing faith in modern humanities (from pedagogy to psychology), which developed theories to abolish sickness, squalor and criminality. These ideas became part of the legislative framework with the introduction of the Prussian Law of Compulsory Education in 1878, which determined that educational measures would be applied to children under 12 years instead of punishment. This led to the introduction of a special sphere of compulsory education on the cusp between guardianship and criminal legislation. The second element was state intervention in the leisure sphere of the youth, which was characterised amongst others by the introduction of public leisure opportunities for the young. These educational measures were strongly influenced by patriotic and paramilitary ideas and maintained a clear distance from autonomous groups such as for example German Youth Movement (Wandervogelbewegung) or the Socialist Workers' Youth (Sozialistische Arbeiterjugend) (Peukert, 1989, p. 311).

It was only the increasing need for personnel which led to a positive impact on women's endeavours to work as carers for the poor. Male carers organised massive protests, as - contrary to the wider professional community - they did not see the work of women as necessary and judged it to be unprofessional. From 1881 a number of municipal administrations - Kassel being an example - started to deploy women as equal carers for the poor, followed by Berlin, Frankfurt, Düsseldorf, Wiesbaden, Magdeburg. In 1907, 4,000 male and 40 female carers were employed in Berlin (for further detail see Salomon, 1901/1997, p. 93; Sachße \& Tennstedt, 1995, p. 214f; Braches-Chyrek, 2013).

The emergence of social work as a profession is inextricably linked with the history of the "Girls' and Women's Groups for Social Service Work" (Salomon 1913). This project is closely associated with Alice Salomon's professional career and influence on the development of social work as a profession. She was closely involved in voluntary welfare work both there and in the "Advice Centre for the German Society for Ethical Culture", later the centre for private welfare, for over a decade.

The original focus of the Girls' and Women's Groups for Social Service Work - supported by the en general, $y$ también la regulación del potencial preocupante y desestabilizador de las masas desfavorecidas y la reforma del insuficiente bienestar privado con la creación de un plan de ayuda más eficaz por parte del estado - para poder lograr el control social imponiendo disciplina social. Estos procesos de cambio se vieron favorecidos por un fortalecimiento general de las creencias y actitudes pedagógicas y la fe creciente en las ciencias humanísticas modernas (desde la pedagogía a la psicología), lo que desarrolló teorías para suprimir la enfermedad, la miseria y la criminalidad. Estas ideas formaron parte del marco legislativo con la introducción del Derecho Prusiano de educación obligatoria en 1878 , lo que determina que las medidas educativas se aplicarían a niños menores de 12 años en lugar del castigo. Esto condujo a la introducción de una esfera especial de la enseñanza obligatoria que se puede situar entre la tutela y la legislación penal. El segundo elemento fue la intervención del estado en la esfera del ocio de la juventud, caracterizado entre otros por la introducción de opciones públicas de ocio para jóvenes. Estas medidas educativas se vieron fuertemente influenciadas por ideas patrióticas y paramilitares y mantuvieron una clara distancia entre grupos autónomos como por ejemplo el Movimiento de Juventud alemán (Wandervogelbewegung) o las Juventudes de Trabajadores Socialista (Sozialistische Arbeiterjugend) (Peukert, 1989, p. 311).

Debido a la creciente necesidad de personal para el cuidado de los pobres, se produjo un impacto positivo con la colaboración de las mujeres como cuidadoras. Los cuidadores varones organizaron protestas masivas, que - al contrario que en la comunidad profesional - no consideraba necesario el trabajo de las mujeres y lo calificaban como poco profesional. Desde 1881 una parte de las administraciones municipales - por ejemplo la de Kassel - comenzó a igualar a las mujeres como cuidadoras de los pobres, seguida por las de Berlín, Frankfurt, Düsseldorf, Wiesbaden, Magdeburg. En 1907, en Berlín trabajaron 4.000 hombres y 40 mujeres cuidadores (para más detalles véase Salomon, 1901/1997, p. 93; Sachße \& Tennstedt, 1995, p. 214f; Braches-Chyrek, 2013).

La aparición del trabajo social como profesión está íntimamente ligada con la historia de los «Grupos de mujeres y niñas en trabajos de Servicio So-

[ 26 ] HEINZ SUENKER, RITA BRACHES-CHYREK

SIPS - PEDAGOGIA SOCIAL. REVISTA INTERUNIVERSITARIA [1139-1723 (2016) 27, 19-44] TERCERA ÉPOCA 
social ideas of a broad philanthropic community was the recruitment and education of volunteers for social work, however, this quickly changed in the context of educational reforms to a perception of social work as a professional career for women (Salomon, 1918/2000, p. 495). From 1899 onwards, early social science based seminars quickly started to extend to yearly courses and summer schools for the welfare professions, as well as lecture tours, and from 1905 led to the establishment of schools for women. Initiatives such as the Girls' and Women's Groups for Social Service Work provided the decisive impetus for the founding movement between 1909 and 1914, but so did educational organisations, charitable foundations and trust funds, as welfare work at the beginning of the $20^{\text {th }}$ century was largely delivered through voluntary organisations. The newly established schools were mainly financed by churchbased agencies, for example the Women's School of the Inner Mission in Berlin (1909), the charitable Women's School of Social Work in Munich (1909) or the Protestant Social Seminary for women in Elberfeld (1910). The establishment of the non-denominational School of Social Work for Women in 1908 in Berlin by Alice Salomon was the result of her involvement in the national and international middleclass women's movement network, significantly influenced by her. The Girls' and Women's Groups for Social Service Work, whose president she had become following the death of Jeanette Schwerin, were at its centre. This network linked up women scientists with women practitioners in municipal as well as private charities and with women politicians and had an international focus. Professional social work was to engage middle class girls and women into social care services, to expertly prepare them to take on responsible positions in social work and to participate in social reform. Social work started to develop as a discipline ${ }^{5}$, as the subject of professional training and academic study, leading to the establishment of a range of schools, academies and finally higher education institutions, as well as national and international associations, such as the German Conference of Schools of Social Work for Women and the International Association of Schools of Social Work. The school itself became the birth place of conceptual initiatives; enabling pupils to transcend class and state boundaries by using dis- cial» (Salomon 1913). Este proyecto está estrechamente relacionado con la carrera profesional de Alice Salomon e influencia el desarrollo del trabajo social como profesión. Ella estuvo muy involucrada en trabajos de voluntariado de bienestar y en el "Centro de Apoyo para la Cultura Ética alemana", que posteriormente y durante una década sería el centro para el bienestar privado.

El enfoque original de los Grupos de Niñas y Mujeres en trabajos de Servicio Social, apoyados por las ideas sociales de una amplia comunidad filantrópica fue el reclutamiento y la formación de voluntarios en trabajo social. Sin embargo, esto cambió rápidamente en el contexto de reformas educativas con la percepción del trabajo social como una carrera profesional para las mujeres (Salomon, 1918/2000, p. 495). A partir de 1899, las primeras ciencias sociales basadas en seminarios pasaron a ser cursos anuales y cursos de verano para los profesiones de la asistencia social, así como ciclos de conferencias, y desde 1905 dieron paso a la creación de escuelas para mujeres. Iniciativas como Grupos de Niñas y Mujeres en trabajos de Servicio Social proporcionaron un impulso decisivo para el movimiento fundador entre 1909 y 1914, al igual que las organizaciones educativas, fundaciones de caridad y fondos fiduciarios, ya que el trabajo de bienestar a principios del siglo XX se desarrolló en gran parte mediante organizaciones de voluntariado. Las escuelas de reciente creación fueron financiadas principalmente por organismos con sede en la iglesia, por ejemplo la Escuela de la Mujer de la Misión interna en Berlín (1909), Escuela de trabajo Social de las mujeres caritativas en Munich (1909) o el Seminario Social Protestante para mujeres_en Elberfeld (1910). El establecimiento de la escuela laica de trabajo Social para las mujeres en 1908 en Berlín de Alice Salomon fue el resultado de su participación en el movimiento nacional e internacional de mujeres de clase media, significativamente influenciados por ella. Los Grupos de Niñas y Mujeres en trabajos de Servicio Social, de los que fue presidenta tras la muerte de Jeanette Schwerin, era el centro de la red. Esta red de enfoque internacional reunió a mujeres científicas y profesionales a nivel de municipios tanto en organizaciones benéficas como privadas con mujeres dedicadas a la política. El trabajo social a nivel profesional comprometió a mujeres y niñas de clase media en servicios de asistencia 
course to challenge social norms and values. The aim was to develop a new awareness of education (Braches-Chyrek 2013).

The changes were accompanied by a variety of new legislative regulations, for example the National Youth Welfare Law (Reichsjugendwohlfahrtsgesetz (RJWG)). Although the National Youth Welfare Law made children's right to education a leitmotif by giving it a statutory focus, its aim was not the development of an individual's personality as an individual right, but the state's right to be a controlling entity in the lives of children and young people through corrections of the educational processes. This led to the inception of the field of social pedagogy, which to the present day characteristically enmeshes social aid and social control, and combines supportive with restrictively corrective measures, based on nebulous social ideals of normality and associated with debates about the "limits of educability" (Peukert, 1997: 321f) ${ }^{6}$. The more traditional rescue work ${ }^{7}$ - particularly in the context of the education of children and young people - and the charitable welfare work was linked to pedagogical state interventions into private education processes and institutionalised and professionalised through the establishment of new administrative municipal functions - youth welfare departments (Peukert, 1989, p. $313 \mathrm{ff})^{8}$.

Peukert reconstructed this process historically accurately in his groundbreaking study "Limits of Social Discipline: Rise and Crisis of German Youth Welfare 1878 - 1932" (1986; cf. Steinacker, 2007). He provides an analysis of the process of institutionalisation of an educational area of activity in the context of the establishment of bourgeois capitalist society in Germany. Using a socio-cultural approach he makes the example youth welfare accessible to the analysis of social and pedagogical developments by separating out three historically systematic dimensions and their examination: a) the history of youth; b) the history of social pedagogy; c) requirements, possibilities and limits to pedagogical progress. To this end, he reconstructs requirements and consequences of social processes such as pedagogical discourse and conceptual developments.

The historical material for the period 1878 to 1932 make exciting reading, but in addition the study makes significant contribution to the theory debate: in the reality of the area investigated here, the use social, para prepararlas a conciencia con el objetivo de asumir puestos de responsabilidad en trabajo social y participar en la reforma social. El trabajo social comenzó a desarrollarse como disciplina, 5 como parte de la formación profesional y estudios académicos, propiciando la creación de una amplia gama de escuelas, academias y finalmente instituciones de educación superior, así como asociaciones nacionales e internacionales, como la Conferencia de escuelas de trabajo Social para mujeres alemanas y la Asociación Internacional de escuelas de trabajo Social. La propia escuela dio lugar al nacimiento de iniciativas conceptuales; permitiendo que los alumnos tasciendan los límites de clase y el estado mediante el discurso para desafiar las normas y valores sociales. El objetivo fue desarrollar una nueva conciencia de la educación (Branches-Chyrek 2013).

Los cambios venían acompañados por una variedad de nuevas normas legislativas, por ejemplo la Ley Nacional de Bienestar de la juventud (Reichsjugendwohlfahrtsgesetz (RJWG)). Si bien la Ley Nacional de Bienestar de la juventud adoptó el derecho a la educación del niño como leitmotiv dándole un enfoque legal, su objetivo no fue el desarrollo de la personalidad del individuo como derecho individual, sino el derecho del estado a ser una entidad controladora en la vida de los niños y jóvenes a través de las correcciones de los procesos educativos. Esto condujo a la creación del campo de la pedagogía social, que hasta la actualidad comprende la ayuda y control social y que combina el apoyo con medidas correctivas restrictivas, basadas en dudosos ideales sociales de normalidad y asociada a debates sobre los "límites de la educabilidad" (Ley de Peukert, 1997: 321f). ${ }^{6}$ El trabajo de rescate más tradicional7 particularmente en el contexto de la educación de los niños y jóvenes - y el trabajo caritativo de bienestar estaban vinculados a intervenciones pedagógicas estatales en procesos de educación privada, institucionalizados y profesionalizados a través de la creación de nuevas funciones municipales administrativas - departamento de bienestar de la juventud (Peukert, 1989, p. 313 f) ${ }^{8}$.

Peukert reconstruyó este proceso con precisión histórica en su estudio "Límites de la disciplina Social: Auge y Crisis del Estado de Bienestar de la Juventud Alemana 1878-1932» (1986; cf. Steinacker, 2007). Ofrece un análisis del proceso de institucio-

[ 28 ] HEINZ SUENKER, RITA BRACHES-CHYREK 
of pedagogy to redefine social problems with the illusion of social help amounts to both repressive social norming and to politics of exclusion of marginalised groups. Social work therefore deals with problems, which are continuously recreated outside of its reach. Decisive is Peukert's key hypothesis which aims to show that the vision of total social control is strongly challenged by the reality of capitalist processes of reproduction which continuously and structurally inherently continuously produce new spheres beyond social control. ${ }^{9}$

\section{Weimar Republic and National Socialism}

The introduction of reform efforts was overlaid by a general crisis of social pedagogy, which coincided with the crisis of the Weimar Republic as a welfare state (1929 - 1932), and was manifested in the lack of affordability of public help, by scandals in closed welfare institutions (residential care homes), and in problems associated with open youth work. Developed in hegemonic debates, the view that parts of the lower (youth) class could not be disciplined was gaining momentum. The result of this was on the one hand a self-critical revision of the traditional approach to pedagogy in institutions as well as of the liberal methodology of the practice concepts used in social work, and on the other hand an intradisciplinary professional debate in correctional youth custody work about the "limits of educability", which resulted in the establishment of youth concentration camps (Peukert 1989: 323, 331). Alongside the nalización de un espacio educativo de la actividad en el contexto de la creación de la sociedad capitalista burguesa en Alemania. Utilizando un enfoque socio-cultural hace que el bienestar de la juventud sea un ejemplo accesible para el análisis de la evolución social y pedagógica distinguiendo tres dimensiones históricamente sistemáticas y su examen: a) la historia de la juventud; b) la historia de la pedagogía social; c) requisitos, posibilidades y límites al progreso pedagógico. Para ello, reconstruye los requisitos y consecuencias de los procesos sociales como el discurso pedagógico y los desarrollos conceptuales.

El material histórico del período 1878 a 1932 es una lectura apasionante, pero además el estudio hace una contribución significativa a la teoría a debate: en la realidad de la zona investigada; el uso de la pedagogía para redefinir los problemas sociales con la ilusión de la ayuda social tanto para las normas sociales represivas y las política de exclusión de grupos marginados. Por lo tanto, el trabajo social se encarga de los problemas que se recrean continuamente fuera de su alcance. La hipótesis clave de Peukert es decisiva pues pretende mostrar que la visión de control social total se ve muy amenzada por los procesos de reproducción capitalistas reales que de manera continuada y estructural producen de manera inherente nuevas esferas más allá del control social.9

\section{República de Weimar y Nacional Socialismo}

La introducción de los esfuerzos reformistas fue ensombrecido por la crisis de la pedagogía social, que coincidió con la crisis de la República de Weimar y el estado de bienestar (1929-1932), lo cual se manifestó como falta de viabilidad de la ayuda pública, mediante escándalos en las instituciones de bienestar (casas de acogida residenciales), y en problemas asociados con la introducción de los jóvenes en el mundo laboral. Con el desarrollo de debates hegemónicos, la conciencia de que parte de la clase social baja (joven) no podían recibir castigos fue ganando fuerza. Como resultado de esta situación, se produjeron por un lado una revisión de la auto crítica hacia el enfoque tradicional de la pedagogía en las instituciones así como la metodología liberal de los conceptos prácticos empleados en trabajo social, y por otro lado se llevó a cabo un debate interdisciplinar profesional sobre la custodia de los jóvenes en trabajos co- 
critical self analysis of social pedagogy there were increasing demands to exclude the "ineducable", supported by ideologies rooted in racial biology. The discourse focussed on selection, leading to amendments of the National Youth Welfare Law (RJWG) in 1932. During the period of National Socialism, this first introduction of a distinction between those "worthy of education" and the "incorrigible" then led - based on racial biology - increasingly to a selection and elimination dichotomy and was blindly practiced (Peukert, 1989, p. 332f). During the period of $\mathrm{Na}-$ tional Socialism - the German form of fascism - and in the context of the welfare state turning into an indoctrinating propaganda state - social work institutions became regulators of a special kind (see Schnurr 1988) ${ }^{10}$. Education as an essential component of social work took its lead increasingly from the ideology of the national community and was integrated into a system of social control.

The ideology of the national community (Sünker, 2006a; Sünker \& Otto, 1997) was fundamental to the political culture and practice of National Socialism in all spheres of society and used the idea of a person's "community capacity" to steer processes of integration and exclusion in the social work context. Applied through genetic and racial ideology, these processes resulted in control, forced cooperation, elimination, persecution and murder. The ideology of the "national community" provided a reference point for the individual consciousness and as well as the social relationships which developed through the social work institutions into the National Socialist concept of National Welfare and led to everyday social work practice being determined by eugenic and racist ideas. It was all about the destruction of the welfare state and of socio-political discourses of help and support. The usefulness of the individual for the national community, i.e. the compliance and willingness to contribute to this community, became the measure determining access to or exclusion from certain types of social support ${ }^{11}$.

In the blend of "welfare and oppression" and the "caring posturing" of National Socialism's integration and exclusion and strategies to "tame the German working class" work in Mason's analysis, together forced the national community into becoming the total "driven community" where costbenefit analyses characterise ideology and rrectivos sobre "los límites de la educación" que derivó en la creación de los campos de concentración juveniles (Peurkert 1989: 323,331). Junto con el análisis critico personal de la pedagogía social se demandaba cada vez más excluir lo «ineducable», en base a teorías arraigadas en la biología racial. El discurso se basaba en la selección, que condujo a la reforma de la National Youth Welfare Law (RJWG) en 1932. En la época del Nacional Socialismo, la primera vez que se introduce la distinción entre los «que merece la pena educar» y los «incorregibles» dió lugar -en base a la biología racial- a una dicotomía de selección y eliminación que se practicaba a ciegas (Peukert, 1989, p.332f). Durante el periodo del Nacional Socialismo -la palabra alemana para Fascismo$y$ en el contexto de estado de bienestar transformándose en un estado adoctrinador mediante la propaganda -las instituciones de trabajo social se convirtieron reguladores (véase Schnurr, 1988). ${ }^{10}$ La educación comenzó a ser un componente esencial en la educación para la ideología de la comunidad nacional y se integró en el sistema de control social.

La ideología de la comunidad nacional (Sünker, 2006a; Sünker \& Otto, 1997) fue esencial para la práctica y cultura del Nacional Socialismo en todas las esferas de la sociedad y se apoyaba en la idea de una "capacidad comunitaria" personal para dirigir los procesos de integración y exclusión en el contexto del trabajo social. La aplicación de estos procesos mediante la genética y la ideología racial se derivó en el control, la cooperación forzosa, eliminación, persecución y asesinato. La ideología de la «comunidad nacional» proporcionó puntos de referencia para la conciencia individual así como relaciones sociales desarrolladas en instituciones de trabajo social dentro del concepto de Bienestar Nacional del Nacional Socialismo que supuso que el trabajo diario viniese determinado por ideas racistas y eugenésicas. Todo giraba en torno a la destrucción del estado de binestar y los discursos socio-políticos de ayuda y apoyo. La utilidad del individuo para la comunidad nacional, es decir, pertenecia y voluntad de contribuir a su comunidad, se adoptó como la medida determinante para garantizar el acceso o la exclusión a ciertas maneras de ayuda social. ${ }^{11}$

En la tesitura de "bienestar y opresión" y el "empeño del cuidado" de la integración y exclusión del Nacional Socialismo, y estrategias para "controlar a

[ 30 ] HEINZ SUENKER, RITA BRACHES-CHYREK

SIPS - PEDAGOGIA SOCIAL. REVISTA INTERUNIVERSITARIA [1139-1723 (2016) 27, 19-44] TERCERA ÉPOCA 
practice. Social work - with its many spheres of action and institutions- was incorporated into being a means of securing the rule of National Socialism, surviving on the suggestion of everyday normality versus the reality of everyday terror and was focussed on keeping the German nation "healthy" to develop military strength, to win the social Darwinist struggle (Sünker, 1991).

\section{Post-Fascism: theory building and professionalization}

Given the background of the German division after 1945, along with continuations of as well as breaks with National Socialism, efforts to build a welfare state in the Federal Republic of Germany (West Germany) are situated in the context of the postfascist and post-war reconstruction of (private) capitalism. The obvious reason for this is on the one hand the (re)establishment of the legitimacy of the bourgeois-capitalist society and on the other the securing of the loyalty of the masses.

Accordingly, the prime question is always what does the concept of a welfare state mean? Hartwich (1997:12; pp. 54, 283, 314) systematically outlined the alternatives: "In a theoretical model, the fundamental alternatives are a) the establishment of a welfare state based on current ownership and status structures using social policy corrections and interventions to compensate for all parts of society, b) the change of the historically based ownership and status structures through the democratically structured state, to realise the constitutionally enshrined rights, particularly those to freedom and equality in society. This is the key to the interpretation of welfare state principle within the constitution".

In the context of 1968, and as the signature of the era, the democratisation question became - not unexpectedly - significant for social work too. As in the Great Britain and the USA, the political nature of social work, i.e. the recognition of it as a means for the purposes of the ruling classes, has increasingly been accepted in West Germany and was followed by the las clases trabajadoras alemanas" concuerdan con el análisis de Mason, juntos hicieron que la comunidad nacional se convirtiese una "comunidad totalmente dirigida" donde la ideología y prácticas se basaban en el análisis de los coste y benficios. El trabajo social -en todas sus esferas de acción e institucionesse incorporó por ser una manera de asegurar el gobierno del Nacional Socialismo, sobreviviendo en la sugestión de la normalidad del día a día frente a la verdadera realidad del terror diario centrado en mantener a la nación alemanda "sana" para el desarrollo de la fuerza militar, para ganar la guerra social a la lucha Darwinista (Sünker, 1991).

\section{Post- Fascismo: teoría de la construcción y profesionalización}

Dada la teoría de la división alemana posterior a 1945, junto con los continuas rupturas con el Nacional Socialismo, se localizaron esfuerzos para construir un estado de bienestar en la República Federal de Alemania (Alemania Occidental) en el contexto de reconstrucción post-fascista y post-guerra del capitalismo (privado). La razón obvia para esto es por un lado, el re-establecimiento de la legitimidad de la sociedad burguesa capitalista y por otro asegurar la lealtad de las masas.

En consecuencia, la cuestión esencial siempre es ¿̇qué significa el concepto de bienestar? Hartwich (1997:12; pp.54,283,314) señaló estas alternativas: “En un modelo teórico, las alternativas fundamentales son a) la creación de un estado de bienestar basado en la posesión actual y las estructuras de estatus mediante el uso de correcciones e intervenciones de políticas sociales para compensar a todas las partes de la sociedad, b) el cambio de las estructuras tradicionales de pertenencia y estatus mediante un estado estructurado democráticamente, para alcanzar los derechos constitucionales consagrados, particularmente los de libertad e igualdad social. Esto es clave para interpretar el principio de estado de bienestar dentro de la constitución".

En el contexto de 1968, y con los rasgos de la época, la cuestión de democrátización se convirtió - y no por sorpresa- también en relevante a nivel del trabajo social. Como en Gran Bretaña y EE.UU. la naturaleza política del trabajo social, es decir, el reconocimiento del mismo como medio para lograr los 
question of social alternatives and implications for practice (Sünker, 2003; Steinacker \& Sünker 2010).

At the same time, these developments pinpoint the key reference point for the identity and prospects for the foundations of social pedagogy/social work (in the shape of 'Soziale Arbeit') in the here and now. This frame of reference also offers the opportunity to understand the social and scientific location of social pedagogy and social work in West Germany: Whilst social pedagogy has consistently remained located at university level in selected West German universities, social work has had to "work its way up" -from specialist colleges to specialist Higher Education Schools of Social Work to- alongside a massive expansion and professionalisation process -Polytechnic (Fachhochschule) level education. Social work only became significant within the university context through its connection with social pedagogy- as outlined in the context of social work/pedagogy, now generally being referred to as "Soziale Arbeit" (what may be best called "societal work" in English) to encompass both. ${ }^{12}$

The work to develop theory will now be outlined using a few selected examples. 13

The work of Klaus Mollenhauer is largely central for the development and institutionalisation of social work in West Germany - on the one hand in relation to his thesis $(\mathrm{PhD})$ "Ursprünge der Sozialpädagogik in der industriellen Gesellschaft" (1959) (Origins of Social Pedagogy in Industrial Society), on the other because of him moving from the humanities based focus of pedagogy to a stronger social scientific orientation. Coming from the hermeneutically practical tradition of education sciences, he developed an understanding of the relationship between theory and practice early on, which demands the distinction between practice and scientific knowledge. His works on general pedagogy, social pedagogy, the history of pedagogy, aesthetics and educational theory demonstrate his culture theory based interest in identifying the constitutive conditions of subjectivity as a question of educational processes. In his view, the central task of social pedagogy is the process of education. The aim is to achieve education towards self determination and spontaneity by enhancing maturity (Mollenhauer, 1964).

Mediated through his late work on diagnostics in social pedagogy he (in cooperation with Uhlendorf) propósitos de las clases dominantes, ha sido cada vez más aceptado en Alemania Occidental, y tras ello surgió la cuestión sobre las alternativas e implicaciones sociales de la práctica (Sünker, 2003; Steinacker \& Sünker, 2010).

Al mismo tiempo, estos desarrollos señalan los puntos clave de referencia para identificar y prever las bases de la pedagogía social/ trabajo social (en forma de 'Soziale Arbeit') aquí y ahora. Este marco de referencia nos ofrece también la posibilidad de entender la ubicación social y científica de la pedagogía social y trabajo social en Alemania Occidental: Mientras la pedagogía social se ha mantenido de manera constante a nivel universitario en las universidades de Alemania Occidental, el trabajo social "se ha tenido que abrir camino" - desde los colegios especializados hasta Escuelas Superiores de Educación en Trabajo Social- junto con la expansión masiva del proceso de profesionalización - nivel de educación politécnica (Fachhochschule). El trabajo social solo ha tenido relevancia en el contexto universitario mediante su conexión con la pedagogía socialcomo se pone de manifiesto en el contexto del trabajo/pedagogía social, ahora generalmente conocido como "Soziale Arbeit" que engloba a ambas. ${ }^{12}$

Ahora describiremos el trabajo para desarrollar la teoría con algunos ejemplos seleccionados. ${ }^{13}$

El trabajo de Klaus Mollenhauer en gran parte versa sobre el desarrollo y la institucionalización del trabajo social en la República Federal de Alemania - por un lado en relación con su tesis (PhD) "Ursprünge der Sozialpädagogik en der industriellen Gesellschaft" (1959) (Orígenes de la pedagogía Social de la Sociedad Industrial), y por otro debido a su propio enfoque desde las pedagogía y las humanidades a una orientación científica social más fuerte. Desde la práctica hermenéutica de la tradición de las ciencias de la educación, desarrolló la comprensión de la relación entre teoría y práctica desde el principio para lo que es necesario saber distinguir entre conocimiento científico y práctica. Sus trabajos sobre pedagogía general, pedagogía social, la historia de la pedagogía, la estética y la teoría educativa demuestran su interés por la teoría de cultura basada en la identificación de las condiciones constitutivas de la subjetividad como una cuestión de procesos educativos. En su opinión, la tarea principal de la pedagogía social es el proceso de educación.

[ 32 ] HEINZ SUENKER, RITA BRACHES-CHYREK 
he dealt with the relationship between the individual and society in adverse life circumstances and linked this -more or less strongly depending on the stage- to the quest for the essence of pedagogy using social and political theory to reflect on the conditions and possibilities of pedagogy.

Michael Winkler on the other hand formulates a theory of social pedagogy which primarily focuses on social pedagogy as a discipline characterised by discourse (1988; 1995). Social pedagogy focuses on the knowledge of practice, it refers to social practice and is reflexively connected to it. Theory and practice, empirical findings and reflection, thoughts and actions are continuously subjected to critical examination, to develop new ways of understanding and interpreting problem situations for individuals and society. In Winkler's view theory cannot stand still, but should provide categories to be populated by principles and at the same time be able to show contemporarily relevant substance. He believes that observation, analysis and hypothesis are essential to the empirical discourse, as the reflection through discourse transforms the communication structures in social pedagogy into social pedagogical action. The theory of social pedagogy includes two levels, firstly the theory of the real object, the description, analysis of the prerequisites, conditions, structures, functions and limitations and secondly the reflective exploration of these elements in terms of a social construction. The focus of social pedagogy on inclusion constitutes its contribution to social integration. Problems and risks are dealt with in a social-pedagogical way produced in conjunction with the stakeholders and institutions of social work in society. Social work therefore contributes to the creation of the social infrastructure. Social pedagogy, according to Winkler, is interested in the competencies, educational and developmental processes of individual stakeholders in order to create living conditions which secure permanent existences beyond poverty. The clarifying impetus as well as the crucial importance in the works of Michael Winkler lies in the consolidation of the concept of the subject as an independent construct in social work that serves to ask whether social pedagogical institutions and places limit or harm subjectivity and
El objetivo es lograr la educación hacia la autonomía y la espontaneidad aumentando la madurez (MoIlenhauer, 1964).

Con su último trabajo sobre el diagnóstico de la pedagogía social (en colaboración con Uhlendorf) aborda la relación entre el individuo y la sociedad en circunstancias vitales adversas y lo relaciona, de manera más o menos estable dependiendo de la etapa, con la búsqueda de la esencia de la pedagogía utilizando la teoría social y política para reflexionar sobre las condiciones y posibilidades que ofrece la pedagogía.

Por otra parte, Michael Winkler formula una teoría sobre la pedagogía social que se centra principalmente la pedagogía social como una disciplina caracterizada por el discurso (1988; 1995). La pedagogía social se centra en conocer la práctica, se refiere a la práctica social y está recíprocamente conectada con ella. Teoría y práctica, resultados empíricos, reflexión, pensamientos y acciones están continuamente sometidos a examen crítico, a desarrollar nuevos caminos para comprender e interpretar situaciones problemáticas para los individuos y la sociedad. En opinión de Winkler la teoría no puede mantenerse inalterable, sino que debe proporcionar categorías que llenar de principios y al mismo tiempo ser capaz de mostrar contenido relevante a los coetáneos. Él cree que la observación, hipótesis y análisis son esenciales para el discurso empírico, así como la reflexión a través de discurso convierte las estructuras de comunicación en la pedagogía social en la acción pedagógica social. La teoría de la pedagogía social incluye dos niveles, en primer lugar la teoría del objeto real; la descripción, el análisis de los pre-requisitos, condiciones, estructuras, funciones $y$ limitaciones, y en segundo lugar la exploración reflexiva de estos elementos en términos de una construcción social. El enfoque de pedagogía social sobre la inclusión representa su contribución a la integración social. Se tratan los problemas y riesgos en base a la pedagógica social junto con los colaboradores e instituciones de trabajo social de la sociedad. Por lo tanto, el trabajo social contribuye a la creación de infraestructura social. Según Winkler, la pedagogía social se interesa por las competencias, procesos educativos y de desarrollo de los actores individuales para crear unas condiciones de vida que asegure la existencia permanente más allá de la pobreza. El 
which individual opportunities the stakeholders of social work have to live self determined lives (1988; 1995). Similarly, this approach of placing the stakeholder of social work in the centre of theoretical interest was adopted even before educational theory, albeit with a clear focus on the production of educational processes.

The focus placed by Hans Thiersch on everyday life and living environments (2008) and that of Lothar Böhnisch (1988) on "coping with life"14 was developed as a critique of and reorientation against a growing institutionalisation, specialisation and professionalisation in the context of the tensions of the modernising theoretical discourse. The aim was to achieve a stronger focus of social work on its recipients. Particularly Hans Thiersch therefore connects with traditional thinking, like for example Alice Salomon's, without whose concepts the professionalisation and institutionalisation of social work would not have been possible. The aim was to use reforms to reshape all social spheres. Hans Thiersch and Lothar Böhnisch demanded a new self-concept of social work; this is about an extension of the functions and the objective of social work, about strategies for coping with life, with the goal of achieving a successful everyday life for its recipients as a result. It is characterised by the specific methodisation of understanding and action in social pedagogy. This opens up new perspectives on practice through the application of social scientific knowledge to achieve a critical analysis and explanation of the social and especially political conditions.

Building on the tradition of Western Marxism with particular reference to Lefebvre's materialist "Critique of Everyday Life" as well as Heydorn's "Critical Theory of Education" - Heinz Sünker is interested in a social analysis based foundation of social work, an emancipating force, if it is intent on working on capitalist conditions from a democratising stance (Sünker, 1989) ${ }^{15}$. This presents a particular challenge in a capitalist society, where the class structure is based on the reproduction of social inequality and where power and domination contradict the historically achieved opportunities for justice and equality. Social work which is interested in overcoming routine and the curing of symptoms in different fields of practice, has to question its justification for its approaches continuously and has impulso clarificador así como la importancia en la obra de Michael Winkler se encuentra en la consolidación de la concepción del tema como un costructo independiente en trabajo social que sirve para preguntarnos si las instituciones pedagógicas sociales y lugares limitan o dañan la subjetividad cuáles son las oportunidades que tienen los actores del trabajo social para vivir una vida independiente (1988; 1995). Asimismo, este enfoque de colocar a los actores de trabajo social en el centro del interés teórico fue adoptado incluso antes de la teoría pedagógica, aunque enfocado claramente en crear procesos educativos.

Hans Thiersch pone el enfoque en la vida diaria y las condiciones de vida (2008) y en el de Lothar Böhnisch (1988) de "sobrellevar la vida"14 lo desarrolló como una crítica a la reorientación contra una institucionalización creciente, la especialización y profesionalización en el contexto de las tensiones del discurso teórico modernizador. El objetivo era que el trabajo social se centrase más en los receptores. Por lo tanto, y en particular, Hans Thiersch conecta con el pensamiento tradicional, como por ejemplo el de Alice Salomon, sin cuyos conceptos la profesionalización e institucionalización del trabajo social no habrían sido posibles. El objetivo era utilizar las reformas para remodelar todas las esferas sociales. Hans Thiersch y Lothar Böhnisch pretendían llegar a un nuevo concepto de trabajo social; una extensión de las funciones y el objetivo del trabajo social, sobre estrategias para sobrellevar la vida, con el objetivo de lograr como resultado una vida diaria exitosa para sus destinatarios. Se caracteriza por desarrollar una metodología específica de la comprensión y acción en la pedagogía social. Esto abre nuevas perspectivas a la práctica con la aplicación del conocimiento científico social para lograr un análisis crítico y una explicación de las condiciones sociales y políticas principalmente.

En base a la tradición del marxismo occidental, con especial referencia a la materialista de Lefebvre "Crítica de la vida cotidiana", así como "Teoría crítica de la educación" de Heydorn - Heinz Sünker se interesó en el análisis social de trabajo social, una fuerza emancipadora, si se pretende trabajar en condiciones capitalistas a partir de una postura democratizadora (Sünker, 1989). ${ }^{15}$ Lo que presenta un desafío particular a una sociedad capitalista, donde

[ 34 ] HEINZ SUENKER, RITA BRACHES-CHYREK

SIPS - PEDAGOGIA SOCIAL. REVISTA INTERUNIVERSITARIA [1139-1723 (2016) 27, 19-44] TERCERA ÉPOCA 
to renew them under the current conditions. This makes the question of the political productivity of social work proliferate and highlights the importance of the question of the constitutive conditions of subjectivity as a question of the capacity for reflection, social jugdement and politically competent action both on the side of professionals and of clients of social work.

Whilst Heydorn's analysis focuses on the mediation between education and history and education and politics, but at the same time has the educational processes of individuals and their forms of consciousness and actions at its centre, Lefebvre assumes that the critique of everyday life includes a critique of political economics in the Marxist sense and encapsulates it, is designed to explore the social human being who is defined by economic activity, but just as much beyond it (Lefebvre, 1989: 604) ${ }^{16}$.

In contrast to any economism a critical theory of society maintains that in everyday life people have to be conscious of their subjectivity and therefore their capacity to act or to develop their subjectivity. It is important in this context that materialist theories of everyday life, which claim an epistemological approach to portraying macro, meso and micro processes in constitution of social structures and their impact on the disposition of individual existences, lead to a clarification of the nature of the problem as well as a broadening of perspectives in relation to the question of societalisation as well as the education.

Lefebvre argues from the subjectivity perspective for a change of current society through a cultural revolution and therefore for the dissolution of the reified and reifying structures of everyday life. Conveying theories of everyday life and of education and linking back to philosophical tradition, whilst using socratic maieutics as his focus, Lefebvre takes this to mean "to help everyday life to produce a present-absent abundance" (Lefebvre, 1972: 31). This positioning also forms the starting point for his analyses, as he is consistently led by the belief in the necessity of rehabilitating everyday life (Lefebvre, 1977: i, 134-135). The demand for the transformation of everyday life comes alive through the exposure of the hidden treasures of the world of trivialities and leads him to the statement that everyday life has an essential relationship with all activity and encom- la estructura de clases se basa en la reproducción de la desigualdad social y donde el poder y la dominación contravienen las oportunidades de justicia y igualdad conseguidas a lo largo de la historia. El trabajo social pretende sobreponerse a la rutina y los síntomas de curación de los diferentes campos de práctica, y debe cuestionar continuamente la justificación de sus planteamientos y renovarlos en base a las condiciones actuales. Esto hace que la cuestión de la productividad política del trabajo social prolifere y destaque la importancia de la cuestión sobre las condiciones constitutivas de la subjetividad como un tema para reflexionar sobre la capacidad, el juicio social y la acción política competente - tanto por parte de profesionales y como de los clientes del trabajo social.

Mientras que el análisis de Heydorn se centra en la mediación entre educación e historia y educación y política, al mismo tiempo da más importancia a los procesos educativos de las personas y sus formas de conciencia y acciones, Lefebvre asume la crítica del día a día e incluye una crítica de la economía política en el sentido marxista y lo encapsula. Se resume en que está diseñada para explorar el ser humano social que se define por actividad económica, pero va más allá (Lefebvre, 1989: 604). ${ }^{16}$

Frente a cualquier economicismo la critica teórica de la sociedad sostiene que en la vida cotidiana tiene que ser consciente de su subjetividad y por lo tanto su capacidad para actuar o desarrollar su subjetividad. En este contexto cabe destacar que las teorías materialistas de la vida cotidiana, que reclaman un enfoque epistemiológico para enmarcar los procesos constitución de estructuras sociales a nivel macro, medio y micro así como su influencia en la disposición de las existencias individuales, nos llevan a esclarecer la naturaleza del problema así como a incrementar las perspectivas relacionadas con la societalización, así como la educación.

Lefebvre pretende conseguir desde la perspectiva de la subjetividad un cambio en la sociedad actual a través de una revolución cultural y, por tanto, la disolución de las estructuras cosificadas y obsoletas de la vida cotidiana. Con el ánimo de reunificar las teorías de la vida cotidiana y la educación y su relación con la tradición filosófica, partiendo de la base del uso del método socrático, Lefebvre lo emplea para que sea sinónimo de "ayudar a la vida co- 
passes it with its conflicts and differences. If everyday life contains the "rational core, the real centre of practice" (Lefebvre, 1972: 49) and production and reproduction of social relationships have their foundations in everyday life, the fundamental importance of proving the historical character of everyday life becomes clear. Lefebvre bases this historical character on a reconstruction and deconstruction of the historically structural genesis of differentiated and differing forms of everyday life in the context of socially, therefore practically, imparted conditions.

Lefevbre's approach, which ties his theory development to the development of the subject, namely everyday life, leads to an insight into the ambiguous and polyvalent nature of everyday life, which he tries to refine and capture through ever new definitions and approaches, in accordance with the fluid nature of his subject. The overarching category for the description and analysis of everyday life is that of "ambiguity" (Lefebvre, 1975: 14).

The meaning of ambiguity is strengthened by the development of everyday life into mundane routine, called by Lefebvre the "bureaucratic society of controlled consumption" (Lefebvre, 1972: 99-154). The consolidation of these mundane routines as the deficient form of everyday life is a characteristic of late capitalist societies, perpetuated by the support of a threefold movement: firstly it requires societalisation in the form of a "totalisation of society"; secondly in terms of the development of the subjects in the shape of an "extreme individualisation" and thirdly a "particularisation" (Lefebvre, 1978: 140). It is of crucial importance, both socio-politically and social theoretically as well as in relation to the question of the structure and contents of educational processes that the establishment of the "mundaneness as a generalised way of life" (Lefebvre ,1975: $225)$ is linked to a process of internal colonisation (Lefebvre, 1972: 86; 1975:242), which takes place as an invasion of body and senses, space and time through processes of subdivision, the crushing of the coherence of life. This way of life is therefore characterised by a tendency towards passivity and non-participation (Lefebvre, 1975: 120 - 121).

This background of the endangered human being and the world raises the questions of alternatives. This is about a recognition of the mundane and its susceptibility to change, so that the reconstruc- tidiana para producir una abundancia presente- ausente" (Lefebvre, 1972: 31). Este posicionamiento también constituye el punto de partida para su análisis, ya que se guía constantemente por la creencia en la necesidad de rehabilitar la vida diaria (Lefebvre, 1977: i, 134-135). La necesidad de transformar la vida cotidiana cobra fuerza con la exposición de los tesoros ocultos del mundo de las trivialidades y le conduce a concluir que la vida diaria tiene una relación crucial con toda actividad y la abarca con sus conflictos y diferencias. Si la vida cotidiana contiene el "núcleo racional, el centro real de la práctica" (Lefebvre, 1972: 49) y la producción y reproducción de las relaciones sociales tienen su fundamento en la vida cotidiana, la importancia de demostrar el carácter histórico de la vida cotidiana se convierte en esencial. Lefebvre centra este carácter histórico en una reconstrucción y deconstrucción de la génesis estructural históricamente diferenciada y en diferentes formas de la vida cotidiana en el contexto de unas condiciones de origen social.

El enfoque de Lefevbre, que vincula el desarrollo de la teoría al desarrollo de la vida del sujeto, es decir, todos los días, conduce a una visión de la naturaleza ambigua y polivalente de la vida cotidiana, que trata de refinar y capturar mediante nuevas definiciones y enfoques, de acuerdo con su naturaleza volátil. La categoría global para la descripción y análisis de la vida cotidiana es la de "ambigüedad" (Lefebvre, 1975: 14).

El significado de ambigüedad se ve reforzado por el desarrollo de la vida cotidiana en la rutina mundana, llamado por Lefebvre "la sociedad burocrática de consumo controlado" (Lefebvre, 1972: 99-154). La consolidación de estas rutinas mundanas como formas de una vida cotidiana deficiente es una característica de las últimas sociedades capitalistas, perpetuado por el apoyo de un movimiento triple: en primer lugar requiere la societalización como una "totalización de la sociedad"; en segundo lugar en términos del desarrollo de la temática en forma de una “individualización extrema" y, en tercer lugar, la "particularización” (Lefebvre, 1978: 140). Es de vital importancia, tanto a nivel socio-político como social-teórico, así como en lo relativo a la cuestión de la estructura y contenidos de procesos educativos que el establecimiento de la "mundanidad como forma generalizada de la vida" (Lefebvre, 1975: 225) está vin- 
tion work as proactive recognition (Lefebvre, 1975: 122) captures the mundane, which consists of both the life in mundane routine alongside a critical distance from it (Lefebvre, 1972: 105) and itself form the basis for building resistance. A new qualitative dimension is however fundamental here as follows: "the act which inaugurates knowledge and practice is poietic" (Lefebvre, 1975: 123). Poiesis as recognising action and as creative recognition refers to the dimensions of a creative capital that relates back to the importance of - including the aesthetically based - spontaneity as a "new regained spontaneity" or - in Heydorn's education theory based understanding "rationally mediated spontaneity" (Heydorn, 1979).

As this is about a socio and cultural analytically founded "revolutionary project of liberation" (Lefebvre, 1975: 24) and therefore a "transformation of everyday life" (Lefebvre, 1978: 44, 231), it needs to be underpinned by educational policy and practice. Because a critical theory of education has to be understood as a theory of liberation of mankind (Heydorn, 1979; vgl. Sünker, 2006b), social work in this context is to be understood as educational work.

A critical concept of education has therefore focussed its attention on the tensions between the individual and society since its beginnings in antiquity. The constitutive conditions of subjectivity in the context of the dialectic between institutionalised education and human liberation as postulated by Heydorn are to be used as concepts for social work. Social pedagogy and educational theory therefore behave complementary and not only in their orientation. The theory of education is fundamental, if social pedagogy is to avoid becoming a merely a normalising activity, but instead serves the initiation and promotion of educational processes. To understand social pedagogy as a form of institutionalised education - and its contradiction - can be a contribution to addressing the urgent problem of the constitution and reproduction of social inequality (Sünker, 1995a).

Because it is embedded in societal politics and social policy since its inception social pedagogy is not self-contained, but must - as a consequence of its constitutive conditions - be continuously opened up and reflected on in the context of its analytical and practical consequences ${ }^{17}$. In the debate on the question “Does Capitalism have a Future?" we are culado al proceso de colonización interna (Lefebvre, 1972:86; 1975:242), que se produce como la invasión del cuerpo y los sentidos, el espacio y el tiempo mediante procesos de subdivisión, de aplastamiento de la coherencia de vida. Por lo tanto, esta forma de vida se caracteriza por una tendencia a la pasividad y la no participación (Lefebvre, 1975: 120-121).

Este fondo del ser humano y del mundo en peligro de extinción plantea preguntas de alternativas. Se trata de un reconocimiento de lo mundano y su susceptibilidad al cambio, ya que el trabajo de reconstrucción como reconocimiento proactivo (Lefebvre, 1975: 122) captura lo mundano, que consiste tanto en la vida en su rutina mundana como en la distancia crítica (Lefebvre, 1972:105) y partir desde la base para llegar a la resistencia. Sin embargo, es esencial contar con una nueva dimensión cualitativa: "el acto que desata el conocimiento y la práctica es poietico" (Lefebvre, 1975: 123).La poiesis como acción de reconocimiento creativo se refiere a las dimensiones de un capital creativo que otorga importancia a -incluyendo la base estética - la espontaneidad como una "una espontaneidad nueva y recuperada" o- según la teoría de la educación de Heydorn, se basa en entender "la espontaneidad racional mediada" (Heydorn, 1979).

Como se trata de un "proyecto revolucionario de liberación" (Lefebvre, 1975: 24) con base analítica y cultural, estamos hablando de una "transformación de la vida cotidiana" (Lefebvre, 1978: 44,231), que debe estar avalada por la política educativa y la práctica. Dado que una teoría crítica de la educación ha de entenderse como una teoría de la liberación de la humanidad (Heydorn, 1979; vgl. Sünker, 2006b), debemos entender el trabajo social en este contexto como trabajo educativo.

Por tanto, el concepto crítico de la educación ha centrado su atención en las tensiones entre el individuo y la sociedad desde sus comienzos en la antigüedad. Las condiciones constitutivas de la subjetividad en el contexto de la dialéctica entre la educación institucionalizada y la liberación humana como establece Heydorn deben utilizarse como conceptos de trabajo social. La pedagogía social y pedagogía, por tanto,son complementarias no sólo en su orientación. La teoría de la educación es fundamental, ya que la pedagogía social debe evitar convertirse en una simple actividad de normalización, al 
reminded - within the conciousness of the contradictions of capitalism - of possibilities of mediating democracy and the welfare of all: "Democratization has been a real, if not inexorable trend over the past two hundred years. This means that a great many people, including those most loyal to the existing order, came to expect three things in the course of their lives. The first is long years of education, the second is stable and reasonably rewarding employment, and, finally, pensions in older age. Housing could be added to this list of expectations, and efforts to provide housing have also been expensive" (Wallerstein et al., 2013: 172).

It may be that facing the background and the outcomes of the neoliberal 'counterrevolution' the perspective of social peadagogy and social work has to be both being conscious about this list and becoming able fighting social inequalities effectively in favour of these social goods in the interest of a democratisation of our societies and of a "good life" of everyone.

\section{(Translation from the German by Beate Wagner)}

contrario, es la iniciación y promoción de los procesos educativos. Para entender la pedagogía social como una forma de educación institucionalizada y su contradicción, puede ser relevante abordar el urgente problema de la constitución y reproducción de la desigualdad social (Sünker, 1995a).

Dado que se encuentra integrado en la política social y políticas sociales, la pedagogía social desde su creación no es independiente, pero -a consecuencia de sus condiciones constitutivas- debe exponerse continuamente y reflejarse en el contexto de sus consecuencias prácticas y analíticas. ${ }^{17}$ En el debate sobre "¿iel capitalismo tiene futuro?" se nos recuerda dentro de la conciencia de las contradicciones del capitalismo- las posibilidades de mediación de la democracia y el bienestar de todos: "la democratización ha sido una verdadera, si no inexorable tendencia durante los últimos doscientos años. Lo que significa que un gran número de personas, incluyendo los más fieles al orden establecido, esperaban obtener tres cosas a lo largo de sus vidas. La primera son largos años de la educación, la segunda es un empleo estable y razonablemente gratificante $y$, por último, una pensión en la vejez. La vivienda podría añadirse a esta lista de expectativas y esfuerzos, ya que la lucha para tener una vivienda también han sido considerablemente cara "(Wallerstein et al., 2013: 172).

Es posible que frente al entorno y los resultados de la 'contrarrevolución' neoliberal la perspectiva de pedagogia social y el trabajo social tenga que ser consciente de esta lista, así como capaz de luchar contra las desigualdades sociales con eficacia en favor de estos bienes sociales en aras de la democratización de nuestras sociedades y de una "buena vida" para todos. 


\section{Bibliography}

Adorno, Th. W. (1993). Einleitung in die Soziologie (1968). Frankfurt/M.: Suhrkamp

Böhnisch, L. (1988). Der Sozialstaat und seine Pädagogik. Neuwied: Luchterhand

Braches-Chyrek (2013). Jane Addams, Mary Richmond und Alice Salomon. Professionalisierung und Disziplinbildung Sozialer Arbeit. Opladen: Budrich

Füssenhäuser, C. (2005). Werkgeschichte(n) der Sozialpädagogik: Klaus Mollenhauer - Hans Thiersch - HansUwe Otto. Baltmannsweiler: Schneider Hohengehren

Hartwich, H. (1977). Sozialstaatspostulat und gesellschaftlicher Status quo. 2nd ed., Opladen: Westdeutscher Verlag

Hegel, G.W.F. (1967). Philosophy of Right. Transl. T. M. Knox. London/Oxford/New York: Oxford University Press

Heydorn, H.-J. (1979). Über den Widerspruch von Bildung und Herrschaft. Frankfurt/M.: Syndikat

Hornstein, W. (1995). Zur disziplinären Identität der Sozialpädagogik. In H. Sünker (Ed.). Theorie, Politik und Praxis Sozialer Arbeit: Einführungen in Diskurse und Handlungsfelder der Sozialarbeit/ Sozialpädagogik. Bielefeld: Kleine, pp. 12-33

Lenhardt, G., \& Offe, C. (1977). Staatstheorie und Sozialpolitik. In C. v. Ferber \& F. Kaufmann (eds.). Soziologie und Sozialpolitik. Opladen: Westdt. Verl, pp. 98 - 127.

Kocka, J. (1990a). Weder Stand noch Klasse. Unterschichten um 1800. Bonn: Dietz

Kocka, J. (1990b). Arbeitsverhältnisse und Arbeiterexistenzen. Grundlagen der Klassenbildung im 19. Jahrhundert. Bonn: Dietz

Lefebvre, H. (1972). Das Alltagsleben in der modernen Welt. Frankfurt/M.: Suhrkamp

Lefebvre, H. (1975). Metaphilosophie. Frankfurt/M.: Suhrkamp

Lefebvre, H. (1978). Einführung in die Modernität. Frankfurt/M.: Suhrkamp

Lefebvre, H. (1989). La somme et le reste. Paris: meridien klincksiek

Mager, K. (1889). Schule und Leben. Glossen zur Dr. Curtmanns Preisschrift (1846). In: ibid: Gesammelte Werke, 8. Band. Baltmannsweiler: Pädagogischer Verlag Burgbücherei Schneider

Marx, K. (1993). Grundrisse. Foundations of the Critique of Political Economy (Rough Draft). Transl. M. Nicolaus. London: Penguin in association with New Left Review

Mollat, M. (1987). Die Armen im Mittelalter. München: C.H. Beck Verlag

Mollenhauer, K. (1959). Die Ursprünge der Sozialpädagogik in der industriellen Gesellschaft. Eine Untersuchung zur Struktur pädagogischen Denkens und Handelns. Weinheim und Berlin: Belz

Mollenhauer, K. (1964). Einführung in die Sozialpädagogik. Weinheim und München: Belz Verlag

Natorp, P. (1974). Sozialpädagogik. Stuttgart: Fromman

Ortmeyer, B. (2009). Mythos und Pathos statt Logos und Pathos. Zu den Publikationen führender Erziehungswissenschaftler in der NS-Zeit: Eduard Spranger, Hermann Nohl, Erich Weniger und Peter Petersen. Weinheim/Basel: Beltz

Otto, H.-U. (1973) Professionalisierung und gesellschaftliche Neuorientierung. Zur Transformation des beruflichen Handelns in der Sozialarbeit, in: H.-U. Otto/S. Schneider (eds.): Gesellschaftliche Perspektiven der Sozialarbeit. Bd. 1. Neuwied: Luchterhand

Otto, H.-U., \& Thiersch, H. (Eds.) (2014). Handbuch Soziale Arbeit. München: Reinhardt

Peukert, D. (1986). Grenzen der Sozialdisziplinierung. Aufstieg und Krise der deutschen Jugendfürsorge von 1878 bis 1932. Köln: Bund

Peukert, D. (1989). Sozialpädagogik, in: D. Langewiesche/H.-E. Tenorth (eds.): Handbuch der deutschen Bildungsgeschichte. Band V 1918 - 1945. Die Weimarer Republik und die nationalsozialistische Diktatur. München: Beck, 307-336

Sachße, Ch., \& Tennstedt, F. (1980) Geschichte der Armenfürsorge in Deutschland. Vom Spätmittelalter bis zum 1. Weltkrieg. Stuttgart: Kohlhammer

PEDAGogía SOCIAL / TRABAJO SOCIAL EN ALEMANIA [ 39 ] SIPS - PEDAGOGIA SOCIAL. REVISTA INTERUNIVERSITARIA [1139-1723 (2016) 27, 19-44] TERCERA ÉPOCA 
Schaarschuch, A. (1995). Das demokratische Potential Sozialer Arbeit. In H. Sünker (Ed.). Theorie, Politik und Praxis Sozialer Arbeit: Einführungen in Diskurse und Handlungsfelder der Sozialarbeit/ Sozialpädagogik. Bielefeld: Kleine, 48-71.

Steinacker, S. (2007). Der Staat als Erzieher: Jugendpolitik und Jugendfürsorge im Rheinland vom Kaiserreich bis zum Ende des Nazismus. Stuttgart: ibedem-Verlag

Steinacker, S., \& Sünker, H. (2010). Politische Kultur, Demokratie und Bildungspraxis in Deutschland. Mitverwaltung - Selbstbestimmung - Partizipation oder „1968“ im Kontext von Geschichte. Zeitschrift für Pädagogik, 56 (No. 1), 22-36

Steinmetz, G. (1993). Regulating the Social. The Welfare State and Local Politics in Imperial Germany. Princeton: Princeton University Press

Sünker, H. (1989). Bildung, Alltag und Subjektivität. Elemente zu einer Theorie der Sozialpädagogik. Weinheim: Deutscher Studien Verlag

Sünker, H. (1991). Nationalsozialistische Herrschaftssicherung durch Soziale Arbeit: Destruktion wohlfahrtsstaatlicher Ansätze und hilfepolitischer Diskurse in der "Volkspflege". In: Ch. Berg \& S. EllgerRüttgarth. Du bist nichts, Dein Volk ist alles. Forschungen zum Verhältnis von Pädagogik und Nationalsozialismus. Weinheim: Deutscher Studienverlag, 46-59

Sünker, H. (1995a). Soziale Arbeit und Vergesellschaftung der Gesellschaft. In H. Thiersch \& K. Grunwald (Eds.). Zeitdiagnose Soziale Arbeit. Weinheim, S. 185-210

Sünker, H. (ed.) (1995b). Theorie, Politik und Praxis Sozialer Arbeit. Bielefeld: Kleine

Sünker, H. (2003). The Politics of Social Welfare: Critical Perspectives on Contemporary Social work. In H. Sünker, R. Farnen \& G. Széll (eds.): Political Socialisation, Participation and Education. Frankfurt: Peter Lang, 113-130

Sünker, H. (2006a). Community's Discontent: the ideology of Volk community in National Socialism. Policy Futures in Education, 4 (No. 3), 306-319

Sünker, H. (2006b). Politics, Bildung and Social Justice. Perspectives for a Democratic Society. Rotterdam/Taipei: Sense

Sünker, H., \& Otto, H.-U. (eds.) (1997). Education and Fascism. Political Identity and Social Education in Nazi Germany. London/Washington: Falmer

Thiersch, H. (2008). Lebensweltorientierte Soziale Arbeit. Aufgaben der Praxis im sozialen Wandel. Weinheim und München: Juventa

Thiersch, H., \& Grunwald, K. (eds.) (1995). Zeitdiagnose Soziale Arbeit. Weinheim: Juventa

Thole, W. (2005). Grundriss Soziale Arbeit. Wiesbaden: VS Verlag

Vester, M., Oertzen, P. v., Geiling, H., Hermann, T., \& Müller, D. (2001). Soziale Milieus im gesellschaftlichen Strukturwandel. Zwischen Integration und Ausgrenzung. Frankfurt/M.: Suhrkamp

Wehler, H.-U. (1987). Deutsche Gesellschaftsgeschichte 1700 - 1815. München: Beck

Winkler, M. (1988). Eine Theorie der Sozialpädagogik. Stuttgart: Klett-Cotta

Winkler, M. (1995). Die Gesellschaft der Moderne und ihre Sozialpädagogik, in h. Thiersch \& K. Grunwald. Zeitdiagnose Soziale Arbeit. Zur wissenschaftlichen Leistungsfähigkeit der Sozialpädagogik in Theorie und Ausbildung. Weinheim u.a. 155-184

Wallerstein, I., Collins, R., Mann, M., Derluguian, G., \& Calhoun, C. (2013). Does Capitalism Have A Future? Oxford/New York: Oxford University Press 


\section{Notas/Notes}

1 It should be noted that in the context of welfare regulations and measures a distinction is largely no longer made in Germany between social pedagogy and social (welfare) work. Notwithstanding this, specific reflection on both from time to time is important which is why this text refers in some parts not to social work, but to social pedagogy or social (welfare) work. M. Winkler writes in the first paragraph of his large scale study "Eine Theorie der Sozialpädagogik" (A Theory of Social Pedagogy) that: "The theory of social pedagogy is a difficult business, which is not self evident. Its concern can hardly hope for universal agreement, nor does it find preconditions which can be described as sufficiently secure. That is not a new state of affairs, as the dispute about social pedagogy and its appropriate conceptual perception is nearly as old as both the term itself and the interest in the subject. But in the midst of the peculiar simultaneous trends of modernisation and demodernisation which currently distinguish at least the advanced states and societies, the exploration of social pedagogy has gained in political sensitivity. More than that: social pedagogy has become a precarious territory" (Winkler, 1988:11) 2 This is the subject of Wehler's 5 volumes of the work "Deutsche Gesellschaftsgeschichte" (German Social History)

3 This theory of the persistence of social inequality is also confirmed by the latest structural analysis for Germany. This fundamental analysis of classed based social stratification shows "Upper - Middle - Lower" in their current differentiation and distribution accross different class factions with consequences for social conception, political consciousness and self perception (Vester et al 2001)

4 Steinmetz (1993: 5) notes in respect to the socio-historical framework for analysis: "The pre-1914 German welfare state therefore allows one to study the simultaneous existence of at least four distinct types of social policy: poor relief, 'Bismarckian' social insurance, proto-corporatist policies, and modern social work. Although these do not exhaust the full universe of forms of social policy, they represent four distinct and extremely influential strategies for regulating 'the social'. More recent social programs have often operated within the traditions, the specific categories, technologies, and goals, established by these early forms".

5 In the German speaking debate the concept of social work has only become terminologically established in the context of the professionalisation of social work as a career for women. Whilst Marger (1889) and Natrop (1907) define the term and scientific subject area of social pedagogic in their writings, Alice Salomon is the first to attempt definitions of the terms social work and social worker (Sachße \& Tennstedt (1980).

6 Despite the fact that social pedagogues promoted it and that it conformed to national socialist ideology, the Correctional Custody Law (Bewahrungsgesetz) was in the end not passed - in Peukert's view as a result of the competing paramountcy claims between welfare, judiciary and the police (Peukert, 1989:331).

7 Hamburg theologian Johan Hinrich Wichem is considered to be the co-founder of the "Rough House" (Rauhes Haus) near Hamburg, of the Johannesstift (St.John's foundation) in Berlin and of the Inner Mission. It was Wichern's influence that led to the institutionalisation of youth welfare work into rescue establishments in the context of a deeply Christian understanding of welfare; the social and moral conditions in society were thus to be stabilised through external missionary activity (see Niemeyer 1997, p. 71f; see Richter, 2004, p. 89f).

8 This establishes - not only in Peukert's view - the influence of pedagogy on welfare, "All modern welfare work has claimed to aim next to the amelioration of acute suffering to also always educate its beneficiaries to sustain themselves, to live in honourable poverty and especially to meet their duty to work. The restrictive distribution of the type and amount of help to a minimum was its negative manifestation and was designed to be kept to below what could be achieved through the worst paid 'free' work available. Beside this coercion into paid work the offer of job opportunities and training to become accustomed to the discipline of performing at work were to be the positive counterpoint" (Peukert, 1989: 320). This guiding theme is also reflected in Steinmetz's view, who remarks in relation to developments post 1890 under the heading "Scientific Social Work, "Pedagogic methods therefore became central" (Steinmetz, 1993: 199).

9 For a further analysis of this area, also see Steinacker's large study (2007) "Der Staat als Erzieher" ("The State as Educator").

10 Schnurr's historical analysis of the social pedagogy movements during the period of National Socialism highlights diverging intervention concepts of social workers during this time, ranging from participation to misinterpretation, passive as well as active integration into the system of National Welfare (1997).

11 It is also important to note that the proponents of the humanities in the fields of pedagogy and social pedagogy - such as in particular H. Nohl - did not prove as opponents, but as conformers to the system during the time of National Socialism (on this topic, see Ortmeyer, 2009).

12 There is no space here to reconstruct the diverse contributions to the debate around the professionalisation; compare initially as an example in the context of the social scientific turnaround Otto (1973). The process of the development of the discipline and the profession is also essentially outlined in voluminous works such as the Handbuch Soziale Arbeit (Handbook of social work) (Otto \& Thiersch 2014) or the "Grundriss Soziale Arbeit" (Social work - an outline) (Thole 2005). 
13 It is important to note that three "founding fathers" (Mollenhauer, Thiersch,Otto) with their respective very differently focussed bodies of work and schools were essential for building the early foundations for theory development; see Füssenhäuser (2005).

14 Böhnisch's study “Der Sozialstaat und seine Pädagogik “(1988) (The welfare state and its pedagogy) written in the 80ies of the last century was one of three post-doctoral theses laying the foundations of theory and which are still relevant for theory development today - the other two authors being Winkler with "Eine Theorie der Sozialpädagogik" (1988) (A theory of social pedagogy) and Sünker with "Bildung Alltag und Subjektivität. Elemente zu einer Theorie der Sozialpädagogik". (1989) (Education (Bildung), Everyday Life and Subjectivity - Elements of a Theory of Social Pedagogy).

15 These themes - focussed on the question of the constitution of social spend and democratisation at their centre - are analytically also important to Hornstein (1995) and Schaarschuch (1995).

16 This offers an opportunity for conciliation with Adorno's analysis of the relationship between society and the individual, which is fundamental to social work: Adorno initially remarks that "the term society is in fact a term which describes the relationship between human beings" (Adorno, 1993: 68). He continues, "There is no such thing as individuals in the social sense, namely human beings who could exist in their own right and especially exist as workers or could have existed, except in the context of the society they live in and which shapes them to their innermost core, as there is society without its own nature being defined by the individuals; because the process by which it is perpetuated is fundamentally the process of life, of work, of production and reproduction, which is kept alive by the individuals socialised by society" (Adorno, 1993: 69-70).

17 See note $1(!)$

* We want to thank our anonymous reviewers and Prof. Jo Moran-Ellis (Sussex University) for support and comments

1 Ha de tenerse en cuenta que en Alemania el contexto de regulaciones y medidas de bienestar ya no se diferencia entre pedagogia social y trabajo social (bienestar). A pesar de esto, de vez en cuando es importante reflexionar sobre ambos, es por ello que este artículo a veces no se refiere al trabajo social sino a la pedagogía social o trabajo (bienestar) social. Según M. Winkier en el primer párrafo de su trabajo a gran escala "Eine Theorie der Sozialpädagogik" (Una teoría de Pedagogía Social): "La teoría de la pedagogía social es una empresa difícil, ya que no resulta evidente. Es muy complicado ponerse de acuerdo a nivel mundial tanto en su objeto de estudio, como en establecer sus condiciones previas y calificarlas como suficientemente seguras. No se trata de algo nuevo, ya que la disputa de la pedagogía social y su adecuada percepción social es casi tan antigua como el propio término y el interés en la materia. Entre las peculiares tendencias simultáneas de actualización y obsolescencia que actualmente diferencian al menos a estados y sociedades avanzados, la exploración de la pedagogía social ha ganado en sensibilidad política. Más aún: la pedagogía social se ha convertido en territorio precario» (Winkler, 1988:11).

2 Este es el tema de los 5 tomos del trabajo de Wehler "Deutsche Gesellschaftsgeschichte" (Historia Social Alemana).

3 El último análisis estructural de Alemania también confirma la teoría de la persistencia de la desigualdad social. Este análisis de la estratificación social basado en las clases se resume en «Alta -Media -Baja» en su actual diferenciación y distribución junto con las facciones clasistas que terminan por influenciar la concepción social, la conciencia política y la auto percepción (Vester et al. 2001).

4 Steinmetz (1993: 5) escribió en relación con el marco histórico y social para el análisis: "El estado de bienestar alemán previo a 1914 nos permite estudiar la existencia simultánea de al menos cuatro formas diferentes de política social: asistencia a los pobres, seguro social 'Bismarkiano', políticas proto-corporativistas y el trabajo social moderno. Aunque estas no son todas las formas posibles de política social, representan cuatro estrategias distintas y extremadamente influyentes para la regulación de 'lo social'. A menudo, algunos programas sociales más recientes han funcionado en las tradiciones, las categorías específicas, tecnologías y objetivos, establecidos por estas primeras concepciones".

5 En el debate del pueblo alemán sobre el concepto de trabajo social se concibió como terminológico en el contexto de profesionalización del trabajo social como una carrera para mujeres. Mientras que Marger (1889) y Natrop (1907) definían el término y el tema científico de la pedagogía social en sus escritos, Alice Salomon fue la primera en intentar definir los términos trabajo social y trabajador social (Sachße \& Tennstedt (1980).

6 A pesar de que los pedagogos sociales lo promovieron y que se ajustaba a la ideología socialista nacional, la ley de custodia Correccional (Bewahrungsgesetz) finalmente no fue aprobada - resultado según Peukert de las repetidas reclamaciones de supremacía entre bienestar, poder judicial y la policía (Peukert, 1989:331).

7 Se considera al teólogo hamburgués Johan Hinrich Wichem el fundador de la "casa áspera" (Rauhes Haus) cerca de Hamburgo, de la Johannesstift (Fundación Sant John) en Berlín y de la misión interna. La influencia de Wichern condujo a la institucionalización del trabajo de bienestar de la juventud en centros de rescate en el contexto de una comprensión

[ 42 ] HEINZ SUENKER, RITA BRACHES-CHYREK

SIPS - PEDAGOGIA SOCIAL. REVISTA INTERUNIVERSITARIA [1139-1723 (2016) 27, 19-44] TERCERA ÉPOCA 
profundamente cristiana del bienestar; las condiciones sociales y morales en la sociedad se estabilizaron a través de la misionera actividad externa (véase Niemeyer 1997, p. 71f; véase Richter, 2004, p. 89f).

8 Esto establece -no sólo en opinión de Peukert - la influencia de la pedagogía en el bienestar, "todo trabajo de bienestar moderno ha afirmado que su objetivo junto a la mejoría del sufrimiento agudo es siempre educar a sus beneficiarios para que se puedan mantener por sí solos, para vivir en la pobreza con honor y sobre todo para cumplir con su deber de trabajar. La distribución restrictiva del tipo y cantidad de ayuda al mínimo era su manifestación negativa y fue diseñada para mantenerse por debajo de lo que podría lograrse con el peor de los trabajos remunerados 'libre' posible. Junto a esta coacción por el trabajo remunerado la oferta de oportunidades de empleo y formación para acostumbrarse a la disciplina de tener que desarrollar un trabajo debían ser el contrapunto positivo"(Peukert, 1989: 320). Este tema principal se refleja también en el punto de vista de Steinmetz, que lo recalca en relación con el desarrollo posterior a 1890 con el título "Trabajo Social científico, los métodos pedagógicos son esenciales"(Steinmetz, 1993: 199).

9 Para obtener un análisis más profundo en este tema véase el amplio estudio de Steinacker (2007) «Der Staat als Erzieher» ("El estado como educador").

10 El análisis histórico de Schnurr de los movimientos de la pedagogía social durante el periodo del Nacional Socialismo destaca diversos conceptos de intervención desarrollados por trabajadores sociales en la época, desde la participación a la malinterpretación, la integración tanto pasiva como activa en el sistema de Bienestar Nacional (1997).

11 Además es importante destacar los proponentes de las humanidades en los campos de pedagogía y pedagogía social -como H. Nohl a nivel particular- que no los calificó como opuestos sino como conformes al sistema durante el $\mathrm{Na-}$ cional Socialismo (para profundizar en este aspecto, véase Ortmeyer, 2009).

12 No hay espacio suficiente para reconstruir aquí las diversas contribuciones al debate de la profesionalización; comparada inicialmente como se ejemplifica en el contexto de giro científico y social de Otto (1973). Grandes obras como el Handbuch Soziale Arbeit ("Manual de trabajo social)" (Otto \& 2014 Thiersch) o "Grundriss Soziale Arbeit» ("Trabajo Social-un esbozo") (Thole 2005) han descrito el proceso de desarrollo de la disciplina y la profesión.

13 Es importante señalar que los tres "padres fundadores" (Mollenhauer, Thiersch, Otto) con sus respectivas y dispares mentes centradas en el trabajo y las escuelas, son esenciales para la sentar las primeras bases del desarrollo de la teoría; ver Füssenhäuser (2005).

14 El estudio de Böhnisch "Der Sozialstaat und seine Pädagogik" (1988) ("El estado de bienestar y su pedagogía") escrito en los años 80 del siglo pasado fue una de las tres tesis post-doctorales sobre las que se cimentó la teoría y que a día de hoy siguen siendo relevantes para su desarrollo, los otros dos autores fueron Winkler con "Eine Theorie der Sozialpädagogik" (1988) (“Una teoría de pedagogía social”) y Sünker con "Bildung Alltag und Subjektivität. Elemente zu einer Theorie der Sozialpädagogik" (1989) (“Educación, vida cotidiana y subjetividad - elementos de una teoría de pedagogía Social”).

15 Estos temas, centrados en la cuestión de la constitución social y democratización - también son analíticamente importantes para Hornstein (1995) y Schaarschuch (1995).

16 Esto ofrece una oportunidad para la conciliación con el análisis de la relación entre sociedad e individuo según Adorno, fundamental para el trabajo social: Inicialmente, Adorno señala que "el término sociedad es un término que describe la relación entre los seres humanos" (Adorno, 1993: 68). Continúa diciendo "no existe tal cosa como individuos en el sentido social, es decir, seres humanos que podría existir en su propio derecho y sobre todo existen como trabajadores o pudieran haber existido, excepto en el contexto de la sociedad en que viven y que les forma en su interior, ya que la sociedad sin su propia naturaleza viene definida por los individuos; porque el proceso por el que se perpetúa es fundamentalmente el de la vida, del trabajo, de la producción y la reproducción, que la mantiene gracias a la socialización del individuo" (Adorno, 1993: 69-70).

17 Véase nota $1(!)$

* Queremos dar las gracias a los nuestros revisores anónimos y al Profesor Jo Moran-Ellis (Universidad de Sussex) por sus comentarios y apoyo. 


\section{CÓMO CITAR ESTE ARTÍCULO / HOW TO CITE THE ARTICLE}

Suenker, H., \& Braches-Chyrek, R (2016). Social Pedagogy/Social Work in Germany: Theories and Discourses in Social Pedagogy and Social Work: From disciplinarisation of the poor to an emancipatory democratic perspective. Pedagogía Social. Revista Interuniversitaria, 27, 19-44. DOI:10.7179/PSRI_2016.27.03

Fecha de recepción del artículo / received date: IX.IX.2015

Fecha de revisión del artículo / reviewed date: 17.IX.2015

Fecha de aceptación final / accepted date: 15.X.2015

\section{DIRECCIÓN DE LAS AUTORAS/ AUTHORS' ADDRESS}

Heinz Suenker. Wuppertal University. Department G. Gaussstr. 2O, 42119 Wuppertal. Germany E-mail: suenker@uniwuppertal.de.

Rita Braches-Chyrek. Markusplatz 3.96045 Bamberg. Germany E-mail: rita.braches@uni-bamberg.de.

\section{PERFIL ACADÉMICO / ACADEMIC PROFILE}

Heinz Suenker. Prof. of Social Pedagogy/Social Policy at the Wuppertal University since 1991; PhD 1984 and Habilitation 1988 at Bielefeld University, Assissstent Prof. And Associate Prof at Bielefeld University from 1980 to 1991; study of German Philology, Philosophy, Protestant Theology, Education at the Universites of Muenster (1967-1969) and Heidelberg (1969-1976) with state examinations and M.A. (Heidelberg) 1976.

Rita Braches-Chyrek. Prof. of Social Pedagogy at the University of Bamberg since 2013, Phd 2000 and Habilitation 2011 at the University of Wuppertal, Assistent Prof. at the University of Wuppertal from 2008-2012 and 1997-2002, study of social science at die University of Wuppertal 1989-1995, working experience in the field of social work and teacher from 1995 to 1997 and 2002-2008.

[ 44 ] HEINZ SUENKER, RITA BRACHES-CHYREK

SIPS - PEDAGOGIA SOCIAL. REVISTA INTERUNIVERSITARIA [1139-1723 (2016) 27, 19-44] TERCERA ÉPOCA 